\title{
PERBANDINGAN KADAR KORTISOL DALAM SERUM PASIEN PSORIASIS VULGARIS DENGAN BUKAN PASIEN PSORIASIS VULGARIS
}

\author{
Dewi Utami Putri, * Elmeida Effendy, ** Irma Damayanti Roesyanto-Mahadi* \\ *Departemen Ilmu Kesehatan Kulit dan Kelamin \\ ${ }^{* *}$ Departemen Ilmu Kesehatan Jiwa \\ FK Universitas Sumatera Utara/RSUP H. Adam Malik Medan
}

\begin{abstract}
ABSTRAK
Psoriasis adalah suatu penyakit kulit kronis yang secara klasik ditandai oleh daerah kulit memerah dan menebal, ditutupi skuama keperakan. Etiopatogenesisnya kompleks, melibatkan faktor genetik, imunologik dan lingkungan. Kemungkinan adanya kontribusi neuroendokrin pada patogenesis psoriasis cukup menarik perhatian. Kortisol merupakan salah satu profil neuroendokrin yang berinteraksi dengan banyak jalur dalam mencetuskan psoriasis, antara lain regulasi kompartemen epidermis, modulasi respons imun, dan stres.

Penelitian ini bertujuan untuk mengetahui perbedaan kadar kortisol dalam serum antara pasien psoriasis vulgaris dengan bukan pasien psoriasis vulgaris, menggunakan rancangan penelitian analitik dengan pendekatan potong lintang. Penelitian dilakukan sejak bulan Juni sampai Oktober 2016 di RSUP H. Adam Malik Medan. Kadar kortisol dalam serum subyek diperiksa dengan enzyme-linked immunosorbent assay (ELISA). Digunakan uji T-independen untuk menilai perbandingan kadar kortisol dalam serum antara kedua kelompok.

Selama 5 bulan penelitian didapatkan 40 subyek penelitian yang terdiri atas 20 pasien psoriasis vulgaris dan 20 bukan pasien psoriasis vulgaris. Ditemukan kadar rerata kortisol yang lebih rendah dalam serum pasien psoriasis vulgaris $(7,185 \pm 5,04 \mu \mathrm{g} / \mathrm{dL})$ dibandingkan dengan bukan pasien psoriasis vulgaris $(10,390 \pm 3,74 \mu \mathrm{g} / \mathrm{dL})$ yang bermakna secara statistik $(p<0,05)$.

Dari penelitian ini dapat disimpulkan bahwa terdapat perbedaan yang bermakna secara statistik pada nilai rerata kadar kortisol dalam serum antara pasien psoriasis vulgaris dengan bukan pasien psoriasis vulgaris.
\end{abstract}

Kata kunci: psoriasis, neuroendokrin, kortisol

\section{DIFFERENCE OF SERUM CORTISOL LEVEL BETWEEN PSORIASIS VULGARIS AND NON-PSORIASIS VULGARIS PATIENTS}

\section{Korespondensi:}

Jl. Bunga Lau No.17 Medan 20136 Telpon: 082183585595

Email: dewiutamiputri@gmail.com

\begin{abstract}
Psoriasis is a chronic skin disease that is classically characterized by thickened, red areas of skin, covered with silvery scales. Etiopathogenesis of psoriasis is complex, including genetic, immunologic and environmental factors. The possible contributions of environmental neuroendocrine in its pathogenesis is quite interesting. Cortisol is one of neuroendocrine profile which interact with many pathways to induce the disease, including regulation of epidermal compartment, modulation of immune responsse, and stress.

The aim of this study is to determine the difference between serum cortisol level in psoriasis vulgaris and non-psoriasis vulgaris patients, using a cross-sectional analytic study. This study was performed since June until October 2016 in Haji Adam Malik General Hospital Medan. The quantitative measurement of serum cortisol was obtained from enzyme-linked immunosorbent assay (ELISA). The independent T-test was used to determine difference of serum cortisol level between two groups.

During 5 months of study, there were 40 subjects, consist of 20 psoriasis vulgaris patients and 20 nonpsoriasis vulgaris patients. The mean of serum cortisol level in psoriasis vulgaris patients $(7.185 \pm 5.04 \mu \mathrm{g} / \mathrm{dL})$ was significantly lower than non-psoriasis vulgaris patients $(10.390 \pm 3.74 \mu \mathrm{g} / \mathrm{dL})$, with $p$ value $<0.05$.

This study indicate that there is statistically significant difference in the mean levels of serum cortisol between psoriasis vulgaris and non-psoriasis vulgaris patients.
\end{abstract}

Key words: psoriasis, neuroendocrine, cortisol 


\section{PENDAHULUAN}

Psoriasis adalah penyakit kulit inflamasi kronis, secara fenotip ditandai oleh bercak kemerahan meninggi, berbatas tegas, dan ditutupi oleh skuama keperakan seperti mika. Lesi karakteristik psoriasis tersebut disebabkan oleh proliferasi keratinosit yang berlebihan. ${ }^{1,2}$ Terdapat berbagai bentuk lesi psoriasis, antara lain plak, gutata, pustular, eritrodermik, dan inversa. Bentuk yang terbanyak pada hampir $80 \%$ pasien adalah plak, dikenal sebagai psoriasis vulgaris. Lokasinya sering pada daerah ekstensor ekstremitas, bokong, dan kepala. ${ }^{3}$

Psoriasis terjadi secara universal. Prevalensi psoriasis pada populasi berbeda di seluruh dunia berkisar antara $0,1-11,8 \%$. Variasi prevalensi tersebut bergantung pada lokasi geografis, iklim, dan ras. Usia rerata awitan psoriasis bervariasi dari berbagai penelitian, namun hampir $75 \%$ pasien psoriasis memiliki awitan sebelum usia 40 tahun, dan $12 \%$ pasien memiliki awitan pada usia 50-60 tahun. Tidak ada perbedaan prevalensi terhadap jenis kelamin. 4,5

Etiopatogenesis penyakit ini kompleks, melibatkan faktor genetik, imunologik, dan lingkungan. Sebagian besar penelitian yang telah dilakukan fokus pada peran sitokin dan sel imun. Namun, saat ini kontribusi neuroendokrin pada patogenesis psoriasis cukup menarik perhatian, salah satunya kortisol. Kortisol merupakan hormon glukokortikoid endogen pada manusia yang diproduksi di korteks adrenal. Sekresi kortisol memperlihatkan irama sirkadian (variasi diurnal), di mana rentang nilai normal kortisol dalam serum pada remaja dan dewasa pada pagi hari (pukul 07.00-10.00) adalah 3,2-19,4 $\mu \mathrm{g} / \mathrm{dL}$, sedangkan pada sore dan malam hari (pukul 16.00-20.00) adalah 2,3$11,9 \mu \mathrm{g} / \mathrm{dL}{ }^{6,7}$

Melalui interaksi dengan reseptor glukokortikoid di keratinosit, kortisol meregulasi fungsi imun kulit maupun fungsi kompartemen epidermis, dermis, dan adneksa kulit. Kortisol dibutuhkan untuk perkembangan kulit yang sesuai, diferensiasi keratinosit normal, dan pembentukan sawar kulit yang baik. Dinyatakan bahwa berkurangnya produksi kortisol dapat menyebabkan kelainan kulit hiperproliferatif. Selain itu, kortisol memiliki potensi imunosupresif dan anti inflamasi yang diperantarai oleh berbagai sitokin, serta merupakan elemen penting selama periode stres. $^{8-10}$

Saat ini mulai banyak penelitian dilakukan yang ditujukan untuk mengetahui peran neuroendokrin pada psoriasis dan penyakit autoimun lainnya. Namun, masih sedikit penelitian yang fokus pada peran kortisol pada patogenesis psoriasis. Lebih jauh, didapatkan hasil yang bertentangan dalam ekspresi kortisol pada pasien psoriasis dari penelitian-penelitian yang telah ada sebelumnya. Sehubungan dengan hal tersebut penulis melakukan penelitian yang berkaitan dengan kadar kortisol pada pasien psoriasis khususnya di Sumatera Utara.

\section{METODE PENELITIAN}

Penelitian ini merupakan penelitian analitik dengan pendekatan potong lintang. Penelitian telah dilakukan sejak bulan Juni 2016 hingga Oktober 2016, bertempat di Poliklinik Divisi Imunodermatologi SMF Ilmu Kesehatan Kulit dan Kelamin RSUP H. Adam Malik Medan, dan pengambilan serta pemeriksaan sampel darah dilakukan di Instalasi Patologi Klinik RSUP H. Adam Malik Medan. Subyek penelitian adalah pasien psoriasis vulgaris berusia 15-65 tahun yang berobat ke Poliklinik Divisi Imunodermatologi SMF Ilmu Kesehatan Kulit dan Kelamin RSUP H. Adam Malik Medan dan individu sehat sebagai kelompok kontrol. Diagnosis psoriasis vulgaris ditegakkan berdasarkan gambaran klinis yang khas yaitu berupa plak eritematosa yang ditutupi skuama tebal berwarna putih keperakan dengan predileksi pada daerah kulit kepala, garis perbatasan kepala dan rambut, ekstremitas ekstensor, batang tubuh, dan lumbosakral. Pasien psoriasis vulgaris dan kontrol yang sedang hamil, menyusui, menggunakan obat-obat sistemik imunosupresif (kortikosteroid, siklosporin, metotreksat) 4 minggu sebelum dilakukan penelitian, menggunakan obat-obat topikal imunosupresif (kortikosteroid, takrolimus, pimekrolimus) 2 minggu sebelum dilakukan penelitian, dicurigai menderita penyakit infeksi, inflamasi, keganasan gangguan kejiwaan (seperti depresi dan gangguan cemas) serta melakukan aktivitas berat sebelum pemeriksaan tidak diikutsertakan dalam penelitian. Seluruh subyek penelitian telah menandatangani informed consent.

Pengambilan sampel pada penelitian ini menggunakan metode consecutive sampling. Cara pengambilan data penelitian dimulai dengan pencatatan data dasar subyek penelitian yang dilakukan oleh peneliti di Poliklinik SMF Ilmu Kesehatan Kulit dan Kelamin RSUP H. Adam Malik Medan, meliputi identitas pasien, anamnesis, dan pemeriksaan dermatologis. Kemudian dilakukan pengambilan sampel darah oleh petugas laboratorium SMF Patologi Klinik RSUP H. Adam Malik Medan pada jam 8-10 pagi untuk menghindari variasi hasil akibat irama sirkadian. Selanjutnya dilakukan pengukuran kadar kortisol dalam serum dengan enzyme-linked immunosorbent assay (ELISA) analyser menggunakan perangkat dari Architect Abbott (Amerika Serikat). Setelah data terkumpul, data dianalisis secara statistik. Normalitas distribusi data ditentukan dengan uji KolmogorovSmirnov, dan uji T-independen digunakan untuk menilai perbandingan kadar kortisol dalam serum antara kelompok pasien psoriasis vulgaris dengan kelompok bukan pasien psoriasis vulgaris. Batas uji kemaknaan (p) yang digunakan dalam penelitian ini adalah 0,05 .

Pada penelitian ini kontrol yang dimasukkan pada kriteria inklusi kontrol adalah individu sehat. 


\section{HASIL DAN DISKUSI}

Dalam 5 bulan penelitian didapatkan 40 subyek penelitian yang terdiri atas 20 pasien psoriasis vulgaris dan 20 bukan pasien psoriasis vulgaris yang merupakan individu sehat. Karakteristik subyek pada penelitian ini ditampilkan berdasarkan karakteristik demografik pasien psoriasis vulgaris yaitu jenis kelamin, usia, dan suku bangsa, serta berdasarkan lama menderita psoriasis (Tabel 1).

Tabel 1. Karakteristik umum pasien psoriasis vulgaris $(\mathbf{n}=\mathbf{2 0})$

\begin{tabular}{|c|c|c|}
\hline Karakteristik & $\begin{array}{l}\text { Jumlah } \\
\text { (orang) }\end{array}$ & Presentase $(\%)$ \\
\hline \multicolumn{3}{|l|}{ Jenis Kelamin } \\
\hline - Laki-laki & 9 & 45 \\
\hline - Perempuan & 11 & 55 \\
\hline \multicolumn{3}{|c|}{ Kelompok Usia (tahun) } \\
\hline$-\quad<21$ & 2 & 10 \\
\hline$-\quad 21-30$ & 2 & 10 \\
\hline$-\quad 31-40$ & 3 & 15 \\
\hline$-\quad 41-50$ & 8 & 40 \\
\hline$-\quad 51-60$ & 4 & 20 \\
\hline$->60$ & 1 & 5 \\
\hline \multicolumn{3}{|c|}{ Lama Menderita (tahun) } \\
\hline$-<5$ & 6 & 30 \\
\hline$-5-10$ & 4 & 20 \\
\hline$-11-15$ & 3 & 15 \\
\hline$->15$ & 7 & 35 \\
\hline
\end{tabular}

Dari tabel 1 dapat dilihat bahwa jumlah kasus pada jenis kelamin perempuan dan laki-laki hampir sama. Berdasarkan penelitian yang pernah dilakukan di Indonesia, sebagian besar hasil penelitian menunjukkan bahwa jumlah pasien laki-laki lebih banyak daripada perempuan. Seperti penelitian yang dilakukan di RSCM pada tahun 2012 (laki-laki 60\% dan perempuan 40\%) dan di RSUP H. Adam Malik Medan pada tahun 2014 (lakilaki $68 \%$ dan perempuan $32 \%) .{ }^{11,12}$ Meskipun demikian, sebagian besar literatur menyatakan bahwa psoriasis mempengaruhi kedua jenis kelamin secara seimbang. ${ }^{4,5}$

Kejadian psoriasis vulgaris pada subyek kasus penelitian ini memiliki distribusi terbanyak pada kelompok usia 41-50 tahun (40\%), dan terendah pada kelompok usia di atas 60 tahun (5\%). Hasil yang mirip didapatkan dari penelitian yang dilakukan oleh Wardhana, di mana pasien psoriasis terbanyak terdapat pada kelompok usia 30-50 tahun (53\%), dan terendah pada kelompok usia di atas 50 tahun $(18 \%){ }^{13}$ Meskipun psoriasis dapat mengenai semua kelompok usia, namun psoriasis jarang ditemukan pada anak dan terdapat kecenderungan penurunan prevalensi setelah usia 60 tahun. ${ }^{4,14}$

Berdasarkan tabel di atas, kejadian psoriasis vulgaris pada penelitian ini memiliki frekuensi terbanyak pada durasi penyakit lebih dari 15 tahun sebesar 35\%, diikuti oleh $<5$ tahun sebesar $30 \%$ dan 5-10 tahun sebesar 20\%. Hasil tersebut sesuai dengan penelitian yang dilakukan oleh Lin dkk. ${ }^{15}$ (2011) mengenai kualitas hidup dari 480 pasien psoriasis, di mana didapatkan proporsi durasi penyakit tertinggi adalah lebih dari 10 tahun yaitu sebanyak 175 pasien $(38,6 \%)$, diikuti oleh 1-5 tahun $(27,4 \%)$ dan $6-10$ tahun $(26,7 \%){ }^{15}$ Perjalanan psoriasis vulgaris biasanya kronis dengan remisi secara intermiten. Lesi psoriasis dapat menetap selama berbulan-bulan sampai bertahun-tahun pada lokasi yang sama. Meskipun demikian, periode remisi lengkap dapat terjadi. ${ }^{16}$

Perbandingan kadar kortisol dalam serum pasien psoriasis vulgaris (kasus) dengan bukan pasien psoriasis vulgaris (kontrol sehat) dapat dilihat pada tabel 2.

Tabel 2. Perbandingan nilai rerata kadar kortisol diantara subyek penelitian

\begin{tabular}{lcccc}
\hline Subyek & $\mathrm{n}$ & $\begin{array}{c}\text { Rerata } \pm \mathrm{SD} \\
(\mu \mathrm{g} / \mathrm{dL})\end{array}$ & $\begin{array}{c}\text { Nilai minimal- } \\
\text { maksimal } \\
(\mu \mathrm{g} / \mathrm{dL})\end{array}$ & $\mathrm{P}$ \\
\hline Kasus & 20 & $7,185 \pm 5,045$ & $0,2-17,1$ & 0,028 \\
Kontrol & 20 & $10,390 \pm 3,748$ & $5,2-18,7$ & \\
\hline
\end{tabular}

Tabel 2 menunjukkan bahwa terdapat nilai rerata kadar kortisol yang lebih rendah secara bermakna dalam serum pasien psoriasis vulgaris (kasus) dibandingkan bukan pasien psoriasis vulgaris (kontrol sehat). Hasil tersebut mirip dengan penelitian yang dilakukan oleh Weigl ${ }^{17}$ pada tahun 1998 terhadap 70 pasien psoriasis dan 50 kontrol sehat, dimana ditemukan kadar kortisol yang lebih rendah dalam serum pasien psoriasis vulgaris (16 \pm $0,91 \mu \mathrm{g} / \mathrm{dL})$ dibandingkan dengan kontrol sehat $(18 \pm 0,94$ $\mu \mathrm{g} / \mathrm{dL})$. Hasil yang berbeda ditemukan oleh Karanikas dkk. $^{18}$ di Yunani pada tahun 2009, dimana rerata kadar kortisol pada 24 pasien pasien vulgaris $(18,03 \pm 1,98$ $\mu \mathrm{g} / \mathrm{dL})$ lebih tinggi dibandingkan dengan kontrol sehat $(16,94 \pm 1,22 \mu \mathrm{g} / \mathrm{dL})$, meskipun tidak bermakna secara statistik. $^{18}$ Sedangkan Wardhana ${ }^{13}$ yang meneliti profil neuroendokrin pada 32 pasien psoriasis dan 26 kontrol sehat di Bali pada tahun 2012 tidak menemukan perbedaan kadar kortisol yang berarti pada kelompok pasien $(7,80 \pm$ $2,85 \mu \mathrm{g} / \mathrm{dL})$ dengan kelompok kontrol $(8,12 \pm 2,23$ $\mu \mathrm{g} / \mathrm{dL}){ }^{13}$ Beberapa peneliti menyatakan bahwa kadar kortisol yang rendah ini mungkin sama dengan keadaan defisiensi-glukokortikoid ataupun kambuhnya psoriasis setelah penghentian steroid, yang dikenal dengan fenomena steroid-induced psoriasis rebound yang dapat meningkatkan kerentanan terhadap penyakit inflamasi dan autoimun. Sekresi kortisol yang menurun akan menstimulasi proliferasi keratinosit yang berlebihan, mempengaruhi fungsi sawar kulit, dan meningkatkan sitokinsitokin pro-inflamasi yang berperan pada imunitas selular, yang dapat mencetuskan atau mengeksaserbasi psoriasis. $6,10,19$

Distribusi kadar kortisol berdasarkan karaktertistik demografik dan lama menderita penyakit dapat dilihat pada tabel 3 . 
Tabel 3. Distribusi kadar kortisol serum berdasarkan karakteristik demografik pasien $(n=20)$

\begin{tabular}{lccccc}
\hline & \multicolumn{5}{c}{ Kadar kortisol $(\mu \mathrm{g} / \mathrm{dL})$} \\
\cline { 2 - 6 } Jenis kelamin & $\mathrm{n}$ & Rerata & SD & Minimal & Maksmal \\
- Laki-laki & 9 & 7,11 & 5,47 & 0,2 & 14,9 \\
- Perempuan & 11 & 7,24 & 4,93 & 0,5 & 17,1 \\
& & & & & \\
Kelompok usia & & & & & \\
(tahun) & 2 & 4,50 & 0,99 & 3,8 & 5,2 \\
- <21 & 2 & 9,10 & 1,55 & 8,0 & 14,9 \\
- 21-30 & 3 & 6,90 & 5,77 & 0,3 & 11,0 \\
- 31-40 & 8 & 7,08 & 6,28 & 0,2 & 17,1 \\
- 41-50 & 4 & 7,30 & 5,98 & 1,0 & 13,4 \\
- 51-60 & 1 & 9,90 & Tidak & 9,9 & 9,9 \\
- >60 & & & terdefi- & & \\
& & & nisi & & \\
& & & & & \\
Lama menderita & & & & & \\
(tahun) & 6 & 7,81 & 4,56 & 3,5 & 14,9 \\
- <5 & 4 & 6,77 & 4,92 & 0,3 & 11,0 \\
- 5-10 & 3 & 8,90 & 8,46 & 0,2 & 17,1 \\
- 10-15 & 7 & 6,17 & 4,91 & 0,5 & 13,4 \\
- >15 & & & & & \\
\hline
\end{tabular}

Berdasarkan tabel 3 t, ditemukan bahwa kadar kortisol dalam serum lebih rendah pada jenis kelamin lakilaki $(7,11 \mu \mathrm{g} / \mathrm{dL})$ dibandingkan dengan perempuan $(7,24$ $\mu \mathrm{g} / \mathrm{dL})$. Temuan ini berbeda dengan hasil penelitian yang didapatkan oleh Robati dkk ${ }^{20}$ pada tahun 2013 terhadap 30 pasien psoriasis, di mana nilai rerata kadar kortisol dalam serum pasien jenis kelamin perempuan (133,43 \pm 41,85 $\mathrm{ng} / \mathrm{mL})$ lebih rendah dibandingkan dengan laki-laki $(157,12$ $\pm 77,71 \mathrm{ng} / \mathrm{mL}) .^{20}$ Berdasarkan literatur, adapun perbedaan kadar kortisol pada jenis kelamin biasanya hanya bermakna sebelum perempuan mengalami menopause, diduga hal tersebut berkaitan dengan hormonal. $^{21}$

Berdasarkan lama menderita penyakit, ditemukan bahwa nilai rerata kadar kortisol terendah terdapat pada kelompok pasien psoriasis vulgaris dengan durasi penyakit lebih dari 15 tahun $(6,17 \mu \mathrm{g} / \mathrm{dL})$. Peran kortisol pada awitan maupun eksaserbasi psoriasis telah dibahas sebelumnya, namun untuk menentukan apakah ada peran kortisol dalam perjalanan durasi penyakit membutuhkan penelitian lebih lanjut.

\section{SIMPULAN}

Penelitian ini menunjukkan perbedaan yang bermakna secara statistik pada nilai rerata kadar kortisol dalam serum antara pasien psoriasis vulgaris dengan bukan pasien psoriasis vulgaris. Karena itu, kortisol sebagai parameter neuroendokrin mungkin dapat dipertimbangkan pada patogenesis psoriasis terkait pengaruhnya terhadap sistem imun dan sitokin inflamasi yang terlibat pada psoriasis. Penelitian lanjutan dapat dilakukan untuk mengetahui peran kortisol sebagai elemen penting selama periode stres dalam mencetuskan psoriasis dan menghubungkan kadar kortisol dalam serum dengan derajat keparahan psoriasis vulgaris.

\section{DAFTAR PUSTAKA}

1. Cai Y, Fleming C, Yan J. New insights of T cells in the pathogenesis psoriasis. Cell Mol Immunol. 2012;9:302-9

2. Mahajan R, Handa S. Pathophysiology of psoriasis. Indian $J$ Dermatol Venereol. 2013;79:1-9

3. Mitra AD, Mitra A. Clinical presentation of psoriasis. Dalam: Lima H, penyunting. Psoriasis - Types, Causes and Medication. Croatia: InTech; 2013.h. 39-48

4. Parisi R, Symmons DP, Griffiths CE, Ashcroft DM. Global epidemiology of psoriasis: a systematic review of incidence and prevalence. J Invest Dermatol. 2013;133:377-85

5. Coimbra S, Oliveira H, Figueiredo A. Psoriasis: epidemiology, clinical and histology features, triggering factors, assessment of severity, and psychosocial aspect. Dalam: O'Daly J, penyunting. Psoriasis-A Systemic Disease. Croatia: InTech; 2012. h. 69-88

6. Roman JI, Constantin AM, Marina ME, Orasan RI. The role of hormones in the pathogenesis of psoriasis vulgaris. Clujul Med. 2016;89: 1-8

7. Chernecky CC, Berger BJ. Cortisol-plasma or serum. Dalam: Chernecky CC, Berger BJ, penyunting. Laboratory Test and Diagnostic Procedures. Philadelphia: Elsevier Saunders; 2013. h. 388-9

8. Slominski AT, Manna PR, Tuckey RC. Cutaneous glucocorticosteroidogenesis: securing local homeostasis and the skin integrity. Exp Dermatol. 2014;23:369-74

9. Terao M, Itoi S, Murota H, Katayama I. Expression profiles of cortisol-inactivating enzyme, 11ß-hydroxysteroid dehydrogenase-1 in human epidermal tumors and its role in keratinocyte proliferation. Exp Dermatol. 2013;22:98-101

10. Youssef SA, Attia EA, Moussa MH, Mahmoud SA. Glucocorticoid receptor expression in the skin of psoriatic patients compared with control skin: correlation with stress and disease activity and severity. $J$ Egypt Women's Dermatol Society. 2014;11:79-88

11. Setyorini M, Triestianawati W, Wiryadi BE, Alam Jacoeb TN. Proporsi sindrom metabolik pada pasien psoriasis vulgaris berdasarkan kriteria nasional Cholesterol Education Program Adult Treatment panel III di RS dr. Cipto Mangunkusumo dan sebuah klinik swasta di Jakarta. MDVI. 2012;39:2-9

12. Grace, Tanjung C, Roesyanto ID. Hubungan kadar Vascular Endothelial Growth Factor (VEGF) serum dengan skor Psoriasis Area and Severity Index (PASI) pada pasien psoriasis vulgaris di RSUP H. Adam Malik Medan [Tesis]. Medan: Fakultas Kedokteran Universitas Sumatera Utara; 2016.

13. Wardhana M. Stres psikologis pada pasien psoriasis: suatu kajian psikoneuroimunologi. MDVI. 2012;39:10-14

14. Helmick CG, Lee-Han H, Hirsch SC, Baird TL, Bartlett CL. Prevalence of psoriasis among adults in the US: 20032006 and 2009-2010 national health and nutrition examination surveys. Am J Prev Med. 2014;47: 37-45

15. Lin TY, See LC, Shen YM, Liang CY, Chang HN, Lin YK. Quality of life in patients with psoriasis in northern Taiwan. Chang Gung Med. 2011;34:186-96 
16. Grozdev I, Korman NJ. Psoriasis: epidemiology, potential triggers, disease course. Dalam: Weinberg JM, Lebwohl M, penyunting. Advance in Psoriasis. New York: Springer; 2014. h. 27-34

17. Weigl BA. Immunoregulatory mechanisms and stress hormones in psoriasis. Int J Dermatol. 1998; 37: 350-7

18. Karanikas E, Harsoulis F, Giouzepas I, Griveas I, Chrisomallis F. Neuroendocrine stimulatory tests of hypothalamus-pituitary-adrenal axis in psoriasis and correlative implications with psychopathological and immune parameters. J Dermatol. 2009;36:35-44
19. Evers AW, Verhoeven EW, Kraaimaat FW, de Jong EM, de Brouwer SJ, Schalkwijk J, dkk. How stress gets under the skin: cortisol and stress reactivity in psoriasis. $\mathrm{Br} J$ Dermatol. 2010;163:986-91

20. Robati RM, Toossi T, Rahmati-Roodsari M, Khalilazar S, Abolhasani E, Namazi N, dkk. Association of psoriasis severity with serum prolactin, thyroid hormones, and cortisol before and after treatment. Sci World J . 2013:1-5

21. Sofer Y, Osher E, Limor R, Shefer G, Marcus Y, Shapira I, dkk. Gender determines serum free cortisol: higher levels in men. Endocr Pract. 2016;22: 1415-21 